\title{
THE INFLUENCE OF JOB SATISFACTION AND LEADERSHIP STYLE ON EMPLOYEE PERFROMANCE IN CV. PUTRI SION TUNGGUNJAGIR VILLAGE, MANTUP SUB-DISTRICT, LAMONGAN
}

\author{
Nurul Badriyah \\ Faculty of Economics and Business, University of Brawijaya \\ nurulbadriyah19@yahoo.com
}

\begin{abstract}
The development of the business world today more rapidly resulting in tight competition. This is demanding business players in order to leap ahead of the competition with how to improve the quality of human resources and expected employee can improve performance. To be employee performance and the company is also required to pay attention to the factors that can affect the performance of the employees.

This research is a type of quantitative research, data obtained with the spread of the questionnaire to 45 respondents. The population in this research is all employees on $C V$. Putri Sion which numbered 45 people. The Data obtained and then in the analysis using the validity test, test reliability test, classical assumptions, determination coefficient test, $t$ test, $F$ test and multiple linear regression analysis. This research result shows that partially, job satisfaction and leadership style significantly affect to employee performance meanwhile the most dominant affecting performance is employee jobs satisfaction.
\end{abstract}

Keywords: job satisfaction, leadership style, employee performance.

\begin{abstract}
Abstrak
Perkembangan dunia bisnis yang semakin pesat saat ini mengakibatkan persaingan yang ketat. Hal ini menuntut para pelaku bisnis untuk memenangkan persaingan dengan cara meningkatkan kualitas sumber daya manusia dan karyawan diharapkan dapat meningkatkan kinerjanya. Untuk meningkatkan kinerja karyawan, perusahaan diharuskan untuk memperhatikan faktor-faktor yang dapat mempengaruhi kinerja karyawan.

Penelitian ini merupakan jenis penelitian kuantitatif, data diperoleh dengan menyebarkan kuesioner kepada 45 responden. Populasi dalam penelitian ini adalah seluruh karyawan di CV. Putri Sion yang berjumlah 45 orang. Data yang diperoleh kemudian dianalisis menggunakan uji validitas, uji reliabilitas tes, asumsi klasik, uji koefisien determinasi, uji $t$, uji $F$, dan analisis regresi linier berganda. Hasil penelitian ini menunjukkan bahwa secara parsial, kepuasan kerja dan gaya kepemimpinan berpengaruh signifikan terhadap kinerja karyawan sedangkan yang paling dominan mempengaruhi kinerja adalah kepuasan kerja karyawan.
\end{abstract}

Kata Kunci: kepuasan kerja, gaya kepemimpinan, kinerja karyawan.

JEL: J28

\section{Research Background}

Business world development nowadays is growing so fast, causing high competition in every kinds of business, whether in industry, trading company, or services. This thing force business entity to be superior in competition by increasing company performance optimally. Company success not only measured from well-planned business plan but also from the management of human resources that will be the main pawn. 
Good human resources will push the company to move forward and growing. Advanced and sophisticated equipment owned by company will be useless if they are not supported by good human resource.

Good human resource can be observed from a good employee performance. By increasing human resource quality, it is expected employee can improve their performance.

There are previous international researches that have analyzed the relationship between job satisfaction and leadership style to employee performance. Some of them are research conducted by Kelidbari et al. (2016) which states that leadership ethic role in employee performance significantly indirect affect. Mihalcea (2014) research states that leadership affects to employee performance. Bushra et al. (2011) research states that transformational leadership has positive impact to job satisfaction and organization commitment.

Based on the background, thus, this research conducted in order to continue previous researches by taking sample in employee of CV. Putri Sion Tunggunjagir village, Mantup subdistrict, Lamongan. This company is a company in swift nest field. CV. Putri Sion made as research object is based on consideration that human resource role as significant factor. Another consideration is because the decrease in employee performance in CV. Putri Sion. The decrease in performance of employee obviously can harm company because with the decrease in performance can inhibit the company productivity itself. With that problem, manager suggested to increase employee performance by put more attention to employee job satisfaction and leadership style of the company.

\subsection{Job Satisfaction}

In The definition which states that job satisfaction is a behavior of employee to the work that related to work situation, collaboration between employees, rewards received in works, and many other things that related to physical and psychological factors (Sutrisno 2006)

According to Handoko (2012) job satisfaction is an emotional state that is pleasant or unpleasant in which the employees look up to their work. Job satisfaction represent a person's feeling for the work.

\subsection{Leadership Style}

According to Thoha (2010) leadership style is a behavioral norm used by someone when that person wants to influence other people or their underling behavior.

Leadership style basically can be seen from different perspectives. If it is seen from the leadership behavior perspective, just as stated by Tannenbaum and Schmidt in Sutrisno (2016) in which leadership behavior forms a continuum from autocratic to democratic natures. According to him, the extreme behavior influenced by authority usage intensity by leader and use of freedom by follower. The combination between those two factors that determine in which level a leader applies leadership behavior.

\subsection{Employee Performance}

According to Torang (2013) performance is the quantity and or quality of individual or group performance result within organization in doing the main duty and function that guided by norm, standard operating procedure, criteria, and size that have been set or applied in organization. According to Fahmi (2013) performance is result obtained by an organization whether it is a profit oriented or nonprofit oriented which gained through one-time period.

\section{Research Method}

This research uses 45 people as samples and this research uses quantitative method by saturated sampling technique from total 45 populations. Data analysis uses quantitative method in order to test the hypotheses that have been set, which are: 


\subsection{Multiple Regression Linear}

Multiple regression uses in order to know the amount of impact from each independent variable. (job satisfaction and leadership style to dependent variable (employee performance). This analysis used if the total independent variable is two or more (Sugiyono 2013). The formula is:

$$
Y=a+b_{1} x_{1}+b_{2} x_{2+\cdots}+b_{n} x_{n}
$$

Information:

Y : dependent variable (employee performance)

a : constant

$\mathrm{b}_{1} / \mathrm{b}_{2}:$ regression coefficient

$\mathrm{x}_{1} \quad$ : Job satisfaction

$\mathrm{x}_{2} \quad$ : Leadership Style windows.

Or this calculation can be done by the assistance of SPSS20.0 statistic software for

\subsection{1.t test}

$\mathrm{t}$ statistic test basically shows how far the impact of one explanatory/independent variable individually in explaining dependent variables is, or it is used for testing the influence of each independent variable to dependent variable (Sugiyono 2011). T test counting can be done by the help of SPSS 20.0 statistic software for windows. As for the steps of t test are:

1) Hypotheses zero ( Ho ) and its alternate hypotheses ( $\mathrm{Ha}$ )

2) Determine $t_{\text {count }}$ and $t_{\text {table }}$ by $5 \%$ mistake of two sides testing and $d k=n-k-1$. ( $n=$ sample number; $\mathrm{dk}=$ standard deviation)

3) Determination of acceptance and rejection criteria.

a. If $\mathrm{t}$ count $\leq$ than $\mathrm{t}$ table, Ho is accepted and $\mathrm{Ha}$ is rejected, which mean that there is no significant impact between $\mathrm{X}$ variable to $\mathrm{Y}$ variable.

b. If $\mathrm{t}$ count $\geq \mathrm{t}$ table then $\mathrm{Ha}$ is accepted and Ho is rejected, which means there is a significant impact between variable $\mathrm{X}$ on variable $\mathrm{Y}$.

\subsubsection{F test}

The $\mathrm{F}$ test is used to determine whether the independent variables are able to explain the dependent variable simultaneously or whether the independent variables have a significant impact on the dependent variable together (Sugiyono 2010). This t test calculation can be done with the help of SPSS 20.0 statistics software for Windows.

As for the steps of $F$ test are: job satisfaction and leadership style variables significantly affect the CV. Putri Zion employees performance.

Rejection and acceptance criteria

a) If $F_{\text {count }}>F_{\text {table }}$ then $\mathrm{H}_{0}$ is rejected and $\mathrm{H} 1$ is accepted. This means that all regression coefficients together are not significant

b) If $\mathrm{F}_{\text {count }}>\mathrm{F}_{\text {table }}$ then $\mathrm{H}_{0}$ is rejected and $\mathrm{H} 1$ is accepted. This means that all regression coefficients together are not significant.

If $\mathrm{F}_{\text {count }}<\mathrm{F}_{\text {table }}$ then $\mathrm{H}_{0}$ is accepted and $\mathrm{H} 1$ is rejected. This means that all regression coefficients are together significant. 


\section{Result and Discussion}

\subsection{Multiple Linear Regression}

Multiple linear regression analysis is used to determine the magnitude of each of the independent variables which is job satisfaction and leadership style with employee performance dependent variables.

Multiple linear regression analysis is used to test the fourth hypothesis. The results of calculations using SPSS 20.0 statistical software for Windows are shown in the following table:

Table 1. Multiple Linear Regression SPSS Outputs Results Coefficients ${ }^{\mathrm{a}}$

\begin{tabular}{ccccccccc}
\hline Model & \multicolumn{2}{c}{$\begin{array}{c}\text { Unstandardized } \\
\text { Coefficients }\end{array}$} & $\begin{array}{c}\text { Standardized } \\
\text { Coefficients }\end{array}$ & T & Sig. & \multicolumn{2}{c}{$\begin{array}{c}\text { Collinearity } \\
\text { Statistics }\end{array}$} \\
& B & Std. Error & Beta & & & Tolerance & VIF \\
\hline & 1.784 & 1.831 & & 0.974 & 0.335 & & \\
$\begin{array}{c}\text { (Constant) Job } \\
\text { Satisfaction } \\
\text { Leadership Style }\end{array}$ & 0.592 & 0.106 & 0.588 & 5.566 & 0.000 & 0.682 & 1.466 \\
& 0.330 & 0.104 & 0.336 & 3.178 & 0.003 & 0.682 & 1.466
\end{tabular}

Notes: a. Dependent Variable: employee performance

Source: Processed with SPSS 20.0 for Windows.

The Based on table 1 above, it can be seen that the multiple linear regression equation formed is:

$$
\mathrm{Y}=1,784+0,588 \mathrm{x}_{1}+0,336 \mathrm{x}_{2}
$$

Notes:

$\mathrm{Y} \quad=$ Employee Performance

$\alpha \quad=$ Constant

$\mathrm{X}_{1} \quad=$ Job Satisfaction

$\mathrm{X}_{2} \quad=$ Leadership Style

Based on the multiple linear regression equation above, it can be interpreted as follows: First, The constant $(\alpha)$ of 1.784 shows the magnitude of the effect of job satisfaction (X1), leadership style (X2) on performance improvement, meaning that if the independent variable is 0 (constant), then the performance increase is predicted to be 1.784

Second, job satisfaction regression coefficient (X1) of 0.588 means that if job satisfaction rises by 1 unit then employee performance will increase by 0.588 , which means there is a positive relationship between job satisfaction variables with employee performance, then the more increasing in job satisfaction the more increasing in employee performance, assuming that other variables that are affecting considered as constant $\left(\alpha, X_{2}=0\right)$. Third, leadership style regression coefficient (X_2) of 0.336 means that if the leadership style rises by 1 unit then the increase in performance will increase by 0.336 , which means there is a positive relationship between leadership style and employee performance variables. Assuming that other variables that are influencing considered as constant $\left(\alpha, X_{1}=0\right)$.

From the results of the coefficient, the independent variable above is positive, this means that the independent variable has change of direction in the direction of the dependent variable. In addition, it can be seen that the job satisfaction variable coefficient with the regression coefficient of 0.588 has the greatest value compared to the other independent variable regression coefficient which is the leadership style. Thus it can be concluded that the most dominant factor affecting employee performance is job satisfaction. 


\section{2. $t$ Test}

The $t$ test is used to partially test the independent variable on the dependent variable and is also used to test the first and second hypotheses. This test is done by comparing the value of $\mathrm{t}_{\text {count }}>\mathrm{t}$ table with a significant $0.05(5 \%)$, then partially obtained the following results:

Table 2. SPSS Output T Test Result Coefficients

\begin{tabular}{|c|c|c|c|c|c|c|c|}
\hline \multirow[t]{2}{*}{ Model } & \multicolumn{2}{|c|}{$\begin{array}{l}\text { Unstandardized } \\
\text { Coefficients }\end{array}$} & \multirow{2}{*}{$\begin{array}{c}\text { Standardized } \\
\text { Coefficients } \\
\text { Beta }\end{array}$} & \multirow[t]{2}{*}{$\mathrm{T}$} & \multirow[t]{2}{*}{ Sig. } & \multicolumn{2}{|c|}{$\begin{array}{l}\text { Collinearity } \\
\text { Statistics }\end{array}$} \\
\hline & B & $\begin{array}{l}\text { Std. } \\
\text { Error }\end{array}$ & & & & Tolerance & VIF \\
\hline (Constant) & 1.784 & 1.831 & & 0.974 & 0.335 & & \\
\hline $\begin{array}{c}\text { Job Satisfaction } \\
\text { Leadership }\end{array}$ & 0.592 & 0.106 & 0.588 & 5.566 & 0.000 & 0.682 & 1.466 \\
\hline Style & 0.330 & 0.104 & 0.336 & 3.178 & 0.003 & 0.682 & 1.466 \\
\hline
\end{tabular}

Notes: a. Dependent variable: Employee performance

Source: Proceed with SPSS 20.0 for windows

Based on the results of data analysis in the table above it can be seen that each independent variable has a significant effect on the dependent variable with a significant value (Sig) of less than $0.05(5 \%)$. Based on the tables and steps above, it can be interpreted as follows: First, Job Satisfaction $\left(\mathrm{X}_{1}\right)$, From the results of the t test, the value of $\mathrm{t}_{\text {count }}(5.566)$ is greater than the value of $t_{\text {table }}(2.018)$, so that $t_{\text {count }}=t_{\text {table }}$ where $H_{0}$ is rejected $H_{a}$ is accepted which means there is a significant effect between the variable job satisfaction (X1) on employee performance (Y) on CV. Putri Sion, Tunggunjagir Village, Mantup Subdistrict , Lamongan. Second, Leadership style $\left(\mathrm{X}_{2}\right)$, From the results of the $t$ test, the value of $t_{\text {count }}$ (3.178) is greater than the value of $t_{\text {table }}(2.018)$, so that $t_{\text {count }} \geq t_{\text {table }} H_{0}$ is rejected $H_{a}$ is accepted which means there is a significant impact between leadership style (X2) on employee performance (Y) variables on CV. Putri Sion, Tunggunjagir Village, Mantup Subdistrict, Lamongan.

\subsection{F Test}

The $\mathrm{F}$ test is used to determine whether the independent variables $\left(\left(\mathrm{X}_{1}, \mathrm{X}_{2} \ldots \mathrm{X}_{\mathrm{e}}\right)\right.$ together have a significant effect on the dependent variable (Y). This $\mathrm{F}$ test is used to test the third hypothesis. The results of the F test calculations in this study are as follows.

Table 3. SPSS Output F Test Result ANOVA

\begin{tabular}{cccccc}
\hline Model & Sum of Squares & Df & Mean Square & F & Sig. \\
\hline Regression & 229.980 & 2 & 114.990 & 44.747 & $0.000^{\mathrm{b}}$ \\
Residual & 107.931 & 42 & 2.570 & & \\
Total & 337.911 & 44 & & & \\
\hline
\end{tabular}

Notes: a. Dependent variable: Employee Performance, b. Predictors: (Constant), Leadership Style, Job satisfaction

Source: Processed with SPSS 20.0 for Windows 
From the results of the $F$ test obtained $F_{\text {count }}$ of 44.747 while $F_{\text {table }} 3.22$, because $F_{\text {count }} \geq$ $\mathrm{F}_{\text {table }}$ then $\mathrm{H}_{0}$ is rejected $\mathrm{H}_{\mathrm{a}}$ accepted means that the independent variable (job satisfaction and leadership style) together have a significant effect on the dependent variable (employee performance) on CV. Putri Sion, Tunggunjagir Village, Mantup Subdistrict, Lamongan.

\section{Conclusion}

Based on data obtained from the results of the analysis, it can be withdrawn some conclusions as follows: First, job satisfaction has a partial effect on employee performance on CV. Putri Sion, Tunggunjagir Village, Mantu Subdistrict, Lamongan. Second, the leadership style has a partial effect on employee performance on the CV. Putri Sion, Tunggunjagir Village, Mantup Subdistrict, Lamongan. Third, job satisfaction and leadership style influence simultaneously on performance on CV. Putri Sion, Tunggunjagir Village, Mantup Subdistrict, Lamongan. The last, based on the results of multiple linear regression analysis the equation $\mathrm{Y}=$ $1.784+0.588 \mathrm{x}_{1}+0.336 \mathrm{x}_{2}$ is produced. So that it can be concluded that from the equation generated from the output table Coefficients / Standardized Coefficients Beta can be known that the most dominant variable in improving employee performance is the variable job satisfaction (X1) with a regression coefficient of 0.588 .

\subsection{Recommendation}

Based on the results of research and conclusions above the suggestions that can be given in this study are: First, with the existence of a significant effect on job satisfaction variables in improving employee performance, then CV. Putri Sion, Tunggunjagir Village, Mantup Subdistrict, Lamongan, can maintain job satisfaction factors for better employee performance. Second, CV. Putri Sion Company, Tunggunjagir Village, Mantup Subdistrict, Lamongan, should pay more attention to what leadership style should be applied in the company so that it can improve employee performance. Third, With the simultaneous significant influence between the independent variables of job satisfaction and leadership style and employee performance dependent variables, it is recommended that all independent variables be run together because the two independent variables complement each other to help improve employee performance on the CV. Putri Sion, Tunggunjagir Village, Mantup Subdistrict, Lamongan. For further research, it should add other variables that can affect employee performance, because with the better performance of employees it will also have a good effect on the company.

\section{References}

Bushra F, Naveed A, Usman A. 2011. Effect of Transformational Leadership on Employees Job Satisfaction and Organizational Commitment in Banking Sector of Lahore (Pakistan). International Journal of Business and Social Science. 2: 261 - 267.

Fahmi I. 2013. Manajemen Kinerja Teori Dan Aplikasi. Cetakan ke-3. Bandung: Alfabeta.

Handoko T, Hani. 2012. Manajemen Personalia Dan Sumber Daya Manusia. Yogyakarta: BPFE.

Kelidbari HRR, Fadaei M, Ebrahimi P. 2016. The Role of Ethical Leadership on Employee Performance in Guilan University of medical sciences. Procedia - Social and Behavioral Sciences. 230: 463-470.

Mihalcea, A. 2014. Leadership, Personality, Job Satisfaction and Job Performance. Procedia Social and Behavioral Sciences. 127: 443 - 447.

Sugiyono. 2015. Metode Penelitian Pendidikan. Pendekatan Kuantitatif, Kualitatif, dan R\&D. Bandung: Alfabeta.

Sutrisno E. 2016. Manajemen Sumber Daya Manusia. Edisi pertama. Cetakan ke-8. Jakarta: Prenadamedia. 
Torang S. 2013. Organisasi \& Manajemen (Perilaku, Struktur, Budaya. \& Perubahan Organisasi). Cetakan kesatu. Bandung: Alfabeta. 